TI 2012-072/3

Tinbergen Institute Discussion Paper
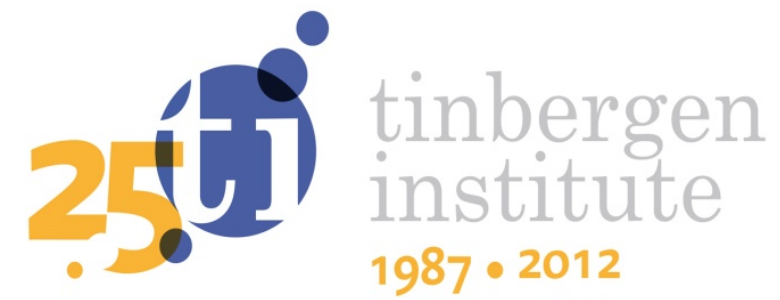

\title{
Production Externalities in the Wood Furniture Industry in Central Java
}

Roos K. Andadari

Henri L.F. de Groot ${ }^{2}$

Piet Rietveld ${ }^{2}$

I Satya Wacana Christian University;

2 Faculty of Economics and Business Administration, VU University Amsterdam, and Tinbergen Institute. 
Tinbergen Institute is the graduate school and research institute in economics of Erasmus University Rotterdam, the University of Amsterdam and VU University Amsterdam.

More TI discussion papers can be downloaded at http://www.tinbergen.nl

Tinbergen Institute has two locations:

Tinbergen Institute Amsterdam

Gustav Mahlerplein 117

1082 MS Amsterdam

The Netherlands

Tel.: +31(0)205251600

Tinbergen Institute Rotterdam

Burg. Oudlaan 50

3062 PA Rotterdam

The Netherlands

Tel.: +31(0)10 4088900

Fax: $+31(0) 104089031$

Duisenberg school of finance is a collaboration of the Dutch financial sector and universities, with the ambition to support innovative research and offer top quality academic education in core areas of finance.

DSF research papers can be downloaded at: http://www.dsf.nl/

Duisenberg school of finance

Gustav Mahlerplein 117

1082 MS Amsterdam

The Netherlands

Tel.: +31(0)20 5258579 


\title{
Production Externalities in the Wood Furniture Industry in Central Java
}

\author{
Roos K. Andadari ${ }^{\mathrm{a}}$, Henri L.F. de Groot ${ }^{\mathrm{b}, 1}$ and Piet Rietveld ${ }^{\mathrm{b}}$ \\ ${ }^{a}$ Satya Wacana Christian University, Faculty of Economics and Business \\ 52-60 Diponegoro Street, Salatiga, Indonesia \\ ${ }^{\mathrm{b}}$ VU University Amsterdam, Dept. of Spatial Economics \\ De Boelelaan 1105, 1081 HV Amsterdam, The Netherlands \\ and Tinbergen Institute, Amsterdam-Rotterdam, The Netherlands
}

\begin{abstract}
This paper exploits micro firm level data to examine the impact of spatial clustering and links to foreign buyer networks on firm performance in the wood furniture industry in Central Java, Indonesia. The analysis is based on an annual manufacturing survey. We identify the impact of specialization of the cluster, diversification, and links to foreign buyer networks. For this purpose, a production function framework is developed. The results lend support to the view that clustering of large and medium scale specialized firms improves firm performance, while clustering of small scale specialized firms and clustering of diverse firms are not conducive to firm performance. We also find a clear positive association between involvement in exporting activities and firm performance.
\end{abstract}

Keywords: $\quad$ Productivity, Externalities, Wood Furniture Industry, Indonesia

JEL codes: $\quad \mathrm{D} 20, \mathrm{R} 11, \mathrm{R} 32$

\footnotetext{
${ }^{1}$ Corresponding author: Henri L.F. de Groot, Dept. of Spatial Economics, VU University Amsterdam, De Boelelaan 1105, 1081 HV Amsterdam, The Netherlands, Email: h.l.f.de.groot@vu.nl. We are grateful to Enno Masurel for comments on earlier versions of this paper. The usual disclaimer applies.
} 


\section{Introduction}

Location externalities, which are derived from industrial clustering, play an important role in fostering competitive advantages and overcoming growth constraints (Schmitz, 1999). Agglomeration theory stresses that the proximity of firms provides benefits, even though the views regarding the sources of the externality benefits are diverse among scholars in this field (see, for example, De Groot et al., 2009, and Melo et al., 2009, for meta-analyses on the empirical evidence of agglomeration externalities). Probably the best-known source of externalities was put forward by Marshall (1920) and was later formalized by Arrow (1962) and Romer (1986). This source is currently known as 'MAR externalities' after Alfred Marshall, Kenneth Arrow and Paul Romer. It emphasizes that knowledge accumulation is predominantly an industry-specific process which benefits from specialization and concentration in space. In contrast, Porter (1990) stresses that clusters enhance growth due to competition among specialized firms which stimulates them to innovate. Finally, Jacobs (1969) insists that agglomeration economies are obtained from the proximity of diverse firms.

However, external benefits enjoyed by firms do not come merely from the spatial concentration of firms, but also from other factors such as linkages with external partners. There is some evidence of firms that perform well without being located in a local cluster (e.g., Shaver and Flyer, 2000). Several studies show that firms, especially in developing countries, can gain advantages by establishing a network with external actors, especially international players. The global value chain (GVC) and global production network (GPN) theories (Gereffi, 1999; Ernst and Kim, 2002) emphasize that a firm can benefit from integration in a global buyer value chain or production network. In addition, the foreign direct investment (FDI) theory developed by Dunning (1993) stresses that becoming a partner in the internationalization decisions of international firms may increase firm's capability by providing access to technology transfer.

Based on the argument that sources of externalities come from location externalities and international network externalities, we propose a simple integrated framework in which externalities cause technological progress and improved firm performance. The changes in technological capabilities can be analyzed in a simple production function framework. The production function reflects the specifications of the minimum input requirements needed to produce designated quantities of output, given the available technology. The traditional production theory emphasizes inputs that are directly related to outputs in the production process with certain technology, in which all of these factors are controllable by management. This theory disregards the external factors beyond the control of firms that influence the relationship behavior between input and output, and the technological progress. This paper aims to examine the impact of externalities on the performance of firms in the wood furniture industry in Central Java. For this purpose, production functions are estimated to analyze the effect not only of the agglomeration economies but also the network with international partners. 
The analysis in this paper is conducted using annual manufacturing surveys from 1994 to 2003 collected by the Indonesian Central Statistical Bureau. ${ }^{2}$ Section 2 describes the research hypotheses and Section 3 explains the research methodology. The profile of wood furniture firms in Central Java is described in Section 4. Results are presented in Section 5, followed by conclusions in Section 6.

\section{Literature review and research hypotheses}

\subsection{Specialization}

The clustering of specialized firms offers benefits for firms inside the cluster that cannot be enjoyed by other firms. This notion goes back to the seminal work of Alfred Marshall and over time different mechanisms have been proposed and empirically tested. It is beyond the scope of this section to discuss this literature at length. All proposed mechanisms rely on the notion that clustering provides externalities and opportunities for joint action that can lead to increasing returns. Knowledge spillovers, opportunities for joint action and sharing a specialized labor force feature prominently in the list of arguments. Conceptually, these were neatly summarized by Duranton and Puga (2004) referring to the benefits of learning, sharing and matching. Based on these insights, we hypothesize that the clustering of the specialized firms has a positive effect on firm performance. More specifically, we will investigate whether the clustering of L\&M specialized firms has a positive effect on firm performance and whether the clustering of small scale specialized firms has a positive effect on firm performance.

\subsection{Diversity}

In a strongly related line of research, several studies have documented that urban location provides benefits of the clustering of diverse firms. Research on the impact of urban location confirms that a city location increases firm productivity (Venables, 2005). Most research on the advantages of urban cities emphasizes the contribution of the advantages of labor (Glaeser and Maré, 2001). However, cities also create an environment conducive to innovation through knowledge spillovers (Acs, 2002). According to Webster and Muller (2000), the competitiveness offered by cities is derived from its unique economic structure, human resources, the institutional environment, and territorial endowments. Rosenthal and Strange (2003) argue that, despite labor market pooling, input sharing, and knowledge spillovers, cities also provide natural advantages, home market effects, consumption opportunities, and rent-seeking advantages. However, in many developing countries, cities have developed as centers of poverty and social collapse (Webster and Muller, 2000), as crime and violence increasingly affect the lives of the

\footnotetext{
${ }^{2}$ BPS distinguishes firms into large (L), medium (M) and small (S) firms. A large firm is a firm that employs at least 100 workers; medium firms employ between 20 and 99 workers; and small firms employ 5 to 19 workers.
} 
people. Consequently, there is a tendency among some scholars to explore the potential of developing small cities (Rondinelli, 1983) giving rise to the fundamental question of optimal city size. In view of these arguments, our second hypothesis therefore is that the clustering of diverse firms has a positive effect on firm performance.

\subsection{Exports}

There is a plethora of research showing that exporting producers have higher productivity than nonexporters (e.g., Aw and Hwang, 1995; Bernard and Jensen, 1995; Aw et al., 1997; Clerides et al., 1998; and Aw et al., 2000). The self-selection theory and learning-by-exporting provide important explanations for this better performance (e.g., Clerides et al., 1998; Bernard and Jensen, 1999). A study on Spanish manufacturing firms (Delgado, 2002) confirms the hypothesis that productivity for exporting firms is higher than for non-exporting firms. However, they find evidence supporting the self-selection argument, whereas learning-by-exporting is rather weak. Meanwhile, research on two new industrialized countries (Aw et al., 2000) provides different evidence. In Taiwan (China), self-selection models can predict variations in productivity, whereas in Korea no statistically significant difference is found in productivity between firms that enter or exit from the export market. As the majority of research indicates that firm exporting has a positive effect on firm performance, further research to test this thesis is needed. Our third hypothesis is therefore that an exporting firm performs better than a non-exporting firm.

\subsection{Foreign ownership}

The hypothesis that foreign-owned firms perform better than domestic firms is supported by much research (e.g., Asheghian, 1982; Kumar, 1984; Grant, 1987). Studies in the US (e.g., Doms and Jensen, 1998; Howensteine and Zeile, 1994) provide evidence that the source of better performance in foreignowned firms is their significantly higher labor productivity than those remaining under domestic ownership, since these firms spend more in employee investments. Howensteine and Zeile (1994) argue that foreign-owned establishments are more capital-intensive and larger. Meanwhile, research in the UK (Griffith and Simpson, 2003; Criscuolo and Martin, 2003) gives the same results. According to Bellak (2004), the difference in performance between foreign firms and domestic firms is caused by differences in productivity, technology, profitability, wages, skills, and growth. Moreover, Douma et al. (2006) argue that the reasons for better performance are due to larger shareholding, higher commitment, and longerterm involvement. The same results are also evident in research on developing countries. Studies in Indonesia (Arnold and Javorcik, 2005) support the above findings. Studies in developed countries provide evidence that better performance is due to the multi-nationality of the firm, rather than the nationality of 
the firm owner, since foreign ownership is much less important. We hypothesize that foreign-owned firms perform better than non-foreign-owned firms.

\section{Research methodology}

\subsection{Model specification}

We now turn to a discussion of the model specification used for the estimation. A production function is used to describe the transformation process in accordance with which inputs are transformed into output, taking into account the contributions of external factors to productivity (cf. Moomaw, 1983; Nakamura, 1985). The analysis rests on a production function that relates the output of firms for a given sector in a region to a number of variables according to $Y=A \cdot f(L, K)$ where $Y$ is output, $A$ is technology (modeled in a Hicks-neutral fashion), $L$ is labor, and $K$ is capital. Typical examples of production functions often used are the so-called Cobb-Douglas and CES production function, the former being a restricted version of the latter. Examples of studies on agglomeration economies employing the Constant Elasticity Substitution (CES) function to examine the impact of externalities in the manufacturing industry are Alperovich (1980) and Calem and Carlino (1990).

In this study we employ the CES production function. There are different versions of the CES function used in the literature, of which the Arrow et al. (1961) model specification has become the standard specification (see Klump and Preissler, 2000). The functional form adopted by ACMS is as follows:

$$
Y_{i t}=A_{i t}\left(\alpha L_{i t}^{-\rho}+(1-\alpha) K_{i t}^{-\rho}\right)^{-\mu / \rho},
$$

where $\alpha$ is a distribution parameter, $\rho$ is a substitution parameter, and $\mu$ captures the economies of scale. In this model the elasticity of substitution is estimated along with dummies for cluster factors and international linkages, characterizing the determinants of $A$ (on which we elaborate below).

In the case of a production function that is characterized by constant returns to scale, $\mu$ equals 1 . The elasticity of substitution between $K$ and $L$ is equal to $1 /(1+\rho)$. We typically assume that $\rho>-1$, to avoid the substitution elasticity from being negative. If the substitution elasticity is zero, the two input factors can be interpreted as perfect complements (the production function is then of the Leontief type). In the case of a substitution elasticity equal to 1, the production function is of the Cobb-Douglas type (viz. $\left.Y_{i t}=A_{i t} L_{i t}^{\alpha} K_{i t}^{(1-\alpha)}\right)$. The Cobb-Douglas production function used to be popular to estimate production functions, but this model is rigid in the sense that it implies that elasticity of substitution between capital and labor equals one by definition. In many cases this assumption is not fulfilled. For some conditions that 
fulfill unitary elasticity of substitution, the Cobb-Douglas production function results are presented as comparisons (see Appendix).

\subsection{Modeling externalities}

As mentioned above, knowledge spillovers in a cluster are the source of dynamic externalities and play a critical role for cluster growth (cf. Glaeser et al., 1992). Due to knowledge spillovers, firms are able to improve their production technology at low costs as they can glean the knowledge from surrounding firms without having to pay for it. In an area in which firms - whether similar or different - are concentrated, people interact either in their own or in other sectors. The proximity of firms becomes important; it can be predicted that an area will grow faster than another less densely populated area. Proximity for firms potentially enhances their performance.

Apart from knowledge spillovers due to firm proximity, there are also externalities from their contacts with an international network consisting of links with foreign buyers in exporting activities, and through ownership. The international network stimulates technological progress through a formal or informal transfer of technology that subsequently increases competitive advantages for firms.

In order to estimate the four factors previously discussed, we model technology (see Glaeser et al., 1992, for a similar approach). The level of technology $A_{i t}$ can be described in the following equation:

$$
A_{i t}=g\left(\text { specialization }_{t}, \text { diversity }_{t}, \text { international ownership }_{i t}, \text { foreign ownership }_{i t}\right)
$$

In equation (2), specialization is a measure of concentration of an industry in an area, which according to MAR and Porter will increase the rate of technological progress. Diversity measures the variety of activities present in an area, which according to Jacobs, speeds up the technological progress. International market linkages increase technological progress due to upgrading (Gereffi, 1999); and foreign linkages, according to Dunning (1993), increase technological progress due to the internalization of knowledge.

The degree of specialization is measured by firm density in the sector. In this analysis we distinguish between L\&M-scale firm density and small-scale firm density. The degree of diversity is measured by the location of firms in urban or non-urban locations. Both indicators are sources of local externalities. The international network externalities variable measures whether the firm is exporting, and whether the firm has a foreigner partnership, or is foreign owned. Apart from those two groups of externalities, time trends also influence technological progress. In the sequel, we make several assumptions on $A_{i t}$ varying from constant over time and type of firms to full variation over time and type of firm. 
In sum, a firm's output is considered to depend both on factors internal to the firm (labor and capital) and on factors external to the firm, the letter being measured by agglomeration economies and international linkages, as identified by $A_{i t}$. These external factors enable a firm to be more productive, since it can attain higher output using the same amount of internal resources.

\subsection{Data, measurement and final model}

We use the plant-level data from an annual manufacturing survey, collected by the Indonesian Central Statistical Bureau (BPS) in which the factory or plant is the unit of observation. Data on firm level production such as output (production value), labor, energy, export orientation, foreign ownership status, and district location are analyzed. To obtain data on proximity, the concentration of firms for each subdistrict is used.

The output measure employed is production value, which refers to the total value of all products produced by a firm using a combination of production/input factors. Our input factors in this study are labor and energy. The energy data is used to substitute for capital, since complete data for machinery is unavailable. Energy expenses cover all types of fuel and energy to run machinery and equipment used in the manufacturing process.

The inclusion of energy in estimating production functions is fairly common in the literature. ${ }^{3}$ Concerning the relationship between capital and energy, the results of the studies vary. Berndt and Jorgenson (1973) find that energy and capital are complements; Pindyck (1979) shows that energy and capital are substitutable; Halvorsen and Ford (1979) show that energy and capital have either significant substitutability or have insignificant complementarity. Regarding the relationship between energy and labor, the findings also vary. Berndt and Wood (1975) find that energy is a substitute for labor, but that it is complementary with capital. However, Griffin and Gregory (1976) find that energy is a substitute for both labor and capital. Meanwhile, Kemfert (1998) reports that aggregate energy, capital, and labor are substitutes in German manufacturing. ${ }^{4}$ From BPS data, the correlation between energy expenses and capital is 0.61 . This correlation coefficient is not as high as we expected, since there are many focus with incomplete coverage of the various types of capital.

\footnotetext{
${ }^{3}$ Studies by Cameron and Schwartz (1980), Field and Grebenstein (1980), and Denny et al. (1981) find differences in estimated substitution elasticities for energy across industries and countries. Walton (1981) finds differences in substitution across US industries. Burney and Al-Matrouk (1996) find substitution between energy and capital in electricity generation and water production in Kuwait. Barnett et al. (1998) show that electricity is a weak substitute for both capital and labor in major Alabama (US) industries.

${ }^{4}$ According to Koetse et al. (2007) estimated technological substitution potential, known as Morishima elasticities, varies considerably over different studies (based on a meta-analysis covering more than 35 studies). The heterogeneity is mostly explained by essential differences in study characteristics, such as model specifications, data characteristics, regions, and time periods. Furthermore, they also found that Morishima elasticities are significantly different from zero for all regions and time periods, especially in the long-run.
} 
Capital and labor are usually included as factors of production. Because the focus of this study is on the impact of externalities on firm performance, several variables relating to location and the international linkage effect discussed above will be added. These are firm density, urban location, exporting status and foreign-ownership. Moreover, in order to incorporate dynamic factors, the variable of time is included.

The data on production value and energy expenditures are in rupiah (Indonesian currency). The value of rupiah changes over time due to the inflation effect. To correct for inflation, the wholesale price index (WPI based on the constant value of $1993^{5}$ ) is used to get the real value of the variables in the analysis. Furthermore, we use the number of workers employed since information regarding the average number of working hours is not available. To capture the changes over time, we use year dummies.

The sample of observations in this study is comprised of all furniture firms in Central Java that employ 20 or more workers and are usually referred to as large and medium scale firms (L\&M). ${ }^{6}$ The data file was compiled from Indonesian wood furniture manufacturing firms and collected via the annual manufacturing surveys of The Indonesian Central Statistical Bureau (BPS). The data was taken at the individual company level from 1994 to 2003, in which each year approximately 200-500 wood furniture firms were recorded. Note that the 1997-1999 years were characterized by a deep economic and political crisis. The BPS staff (a group trained for data collection) assembled the data.

The variables used in this analysis are measured as follows: Production value is the real total value of products produced in a year (in thousand $\mathrm{Rp}$ ); Labor is the average number of workers per working day in a year (in persons); Energy is the real total value of all fuels and energy expenses in a year (in thousand Rp).

Location factors, international network factors, and time are treated as dummy variables:

- $D_{\text {Densl }}$ is a dummy for large and medium scale wood furniture firms' density in one sub-district (kecamatan) which equals 1 when a firm has a coefficient for an L\&M scale density $>0.5$ and 0 otherwise;

\footnotetext{
${ }^{5}$ The Indonesian Wholesale Price Index (WPI) applied here is WPI in the manufacturing sector based on a 1993 constant price $(1993=100)$. The 1993 constant price is computed, based on surveys conducted in 1993 in 126 cities in provincial and district government areas, using 373 commodities. WPI is classified into five groups; Agriculture: 40 commodities; Mining: 8 commodities; Manufacturing: 183 commodities; Importing: 50 commodities; Exporting: 46 commodities; Non-oil/gas: 43 commodities; Oil/gas: 3 commodities (BPS, 2002). The coefficient of WPI in the manufacturing sector from 1993 to 2003 is as follows: in 1993, the index was 100; in 1994 it was 110; in 1995 it was 122; in 1996 it was 126; in 1997 it was 131; in 1998 it was 217; in 1999 it was 268; in 2000 it was 278; in 2001 it was 309; in 2002 it was 339; and in 2003 it was 354. The index for 1994 to 1997 is the author's calculation, since the available data are only based on a 1983 constant price. In this calculation, adjustments were made to transform the 1983 constant price into a 1993 constant price (Source: Indonesian Financial Statistics, The Bank of Indonesia, December 2004; August 2003; November 2002; and December 1999).

${ }^{6}$ The classification used by the BPS is that medium firms employ 20 to 99 workers, whereas large firms employ 100 or more workers.
} 
- $\quad D_{\text {Dens2 }}$ is a dummy for small scale wood furniture firms' density in one sub-district (kecamatan) ${ }^{7}$ which equals 1 when a firm has a coefficient for an small scale firms' density $>10$ and 0 otherwise;

- $D_{u r b}$ is a dummy variable for urban firms which equals 1 when a firm is a located in an urban area and 0 otherwise;

- $D_{\exp }$ is a dummy variable for exporters which equals 1 when a firm is (partly) exporting and 0 otherwise;

- $D_{f o r}$ is a dummy variable for foreign-owned firms which equals 1 when a firm has foreign shares and 0 otherwise;

- $D_{94}$ to $D_{03}$ are year dummies for the years 1994-2003.

The final model that we estimate is as follows:

$$
\begin{aligned}
\ln Y_{i t}=\beta_{0}- & \beta_{1} \ln \left(\beta_{2} L_{i t}^{-\beta_{3}}+\left(1-\beta_{2}\right) K_{i t}^{-\beta_{3}}\right)+\beta_{4} D_{\text {Dens } 1 i t}+\beta_{5} D_{\text {Dens } 2 i t}+\beta_{6} D_{U r b i t} \\
& +\beta_{7} D_{\text {expit }}+\beta_{8} D_{\text {forit }}+\beta_{9} D_{94 i}+\ldots \ldots \ldots \ldots .+\beta_{18} D_{03 i}+e_{i t}
\end{aligned}
$$

The parameters relate to the parameters of the production function: $\beta_{1}=-\mu / \rho ; \beta_{2}=\alpha ; \beta_{3}=-\rho$. The parameter $\beta_{0}$ represents the constant part of $A_{i t}$. Parameter $\beta_{4}, \beta_{5}, \beta_{6}, \beta_{7}$ and $\beta_{8}$ capture the part of $A_{i t}$ that varies over types of firms and $\beta_{9}$ to $\beta_{18}$ capture the time variation. In order to test whether the production function is constant returns to scale and the substitution elasticity equals 1, a Wald test is applied to check whether the $\mu=1$ and $\rho=0$.

\section{The profile of the wood furniture industry in Central Java}

This section provides a short description of the wood furniture industry in Central Java. Although the industry consists of L\&M scale, small scale, and micro scale firms, the L\&M firms are presumed to represent the industry, since there is no data available for small scale for all the years and no data available for micro scale firms. Table 1 displays the development in the number of firms, number of workers employed, total production value, and the number of districts and sub districts where the L\&M scale wood furniture firms are located.

\footnotetext{
${ }^{7}$ Dens $_{1}$ represents large and medium scale firm density which is determined based on the number of large and medium scale wood furniture firms in a $\mathrm{km}^{2}$ area in a particular sub-district. However, Dens $s_{2}$ represents small scale wood furniture firm density which is determined based on the number of small scale firms per $\mathrm{km}^{2}$ area in a particular sub-district. The small scale firm data is taken from the small scale survey done by BPS in 2002. We used the growth rate of Jepara small firms to estimate number of small scale firms for other areas and for other years
} 
Table 1. The development of L\&M scale wood furniture firms in Central Java from 1994 to 2003

\begin{tabular}{lccccccc}
\hline Year & \multicolumn{2}{c}{ \# of L\&M scale firms } & \# of workers & $\begin{array}{c}\text { Real production } \\
\text { (in million rupiah) }\end{array}$ & \multicolumn{2}{c}{ \# of coverage areas } \\
& Total & Medium & Large & Total & Total & Districts & Sub-districts \\
\hline 1994 & 220 & 176 & 44 & 19,534 & 178,315 & 21 & 52 \\
1995 & 339 & 286 & 53 & 25,120 & 229,259 & 25 & 67 \\
1996 & 419 & 346 & 73 & 30,655 & 335,633 & 24 & 75 \\
1997 & 447 & 346 & 101 & 37,169 & 540,489 & 25 & 80 \\
1998 & 464 & 349 & 115 & 50,957 & 874,879 & 25 & 75 \\
1999 & 500 & 383 & 117 & 49,667 & 696,538 & 27 & 79 \\
2000 & 507 & 385 & 122 & 48,712 & 639,336 & 27 & 92 \\
2001 & 483 & 359 & 124 & 50,378 & 679,368 & 26 & 88 \\
2002 & 483 & 372 & 111 & 42,570 & 458,982 & 28 & 89 \\
2003 & 448 & 340 & 108 & 39,614 & 432,950 & 25 & 75 \\
\hline
\end{tabular}

Source: own calculations based on BPS 2004.

Note: data cover all L\&M firms in all areas in Central Java.

Table 1 shows that, from 1994 to 2000, the number of L\&M scale firms in Central Java and the number of districts and sub-districts where the firms were located has expanded. The number of districts and subdistricts has not changed much since 2000. The real total production value of L\&M scale firms grew by almost 50\% annually from 1994 to 1998, compared to a reduction of nearly 12\% from 1999 to 2003 . This growth occurred together with a 22\% growth in the number of firms between 1994 and 1998, compared to a reduction of $0.6 \%$ from 1999 to 2003, whereas the labor employed grew by almost 27\% between 1994 and 1998, compared to a reduction of nearly 4.7\% from 1999 to 2003 . From 1997 to 1998 the wood furniture industry performed well, when many other Indonesian export products were affected by the onset of the economic crisis beginning in mid-1997. This industry enjoyed the devaluation of currency since the products became cheaper in the international market.

A qualitative interview (held in 2007) with the officer from the provincial industrial office indicates that the trend of number of firms, number of workers, and production value after 2003 has tended to decline. The increase in competition from other Asian countries such as China and Vietnam, and the shortage in the wood supply nationwide are to blame as the causes of this decline. However, this change is also caused by changes in the world market demand which affect the industry and firms in all areas. By comparing different areas, the decline in terms of production value and number of workers occurred in all areas, but in relation to the number of firms, the decline in the number of L\&M firms is found in Jepara, while the other clusters tend to increase. The isolated areas do not give a clear picture, 
but nevertheless tend to decline. The spatial distribution of the number of L\&M scale firms is described in Table 2.

Table 2. Distribution of L\&M scale firms in Central Java from 1994 to 2003 according to area

\begin{tabular}{|c|c|c|c|c|c|c|c|c|c|c|c|c|}
\hline \multirow{3}{*}{ Year } & & & \multicolumn{10}{|c|}{ Semarang } \\
\hline & \multicolumn{2}{|c|}{ Jepara } & \multicolumn{2}{|c|}{ Klaten } & \multicolumn{2}{|c|}{ Sukoharjo } & \multicolumn{2}{|c|}{ City } & \multicolumn{2}{|c|}{ Other } & \multicolumn{2}{|c|}{ Total } \\
\hline & $n$ & $\%$ & $n$ & $\%$ & $n$ & $\%$ & $n$ & $\%$ & $n$ & $\%$ & $n$ & $\%$ \\
\hline 1994 & 145 & 65.9 & 11 & 5.0 & 6 & 2.7 & 8 & 3.6 & 50 & 22.7 & 220 & 100.0 \\
\hline 1995 & 234 & 69.0 & 15 & 4.4 & 9 & 2.7 & 11 & 3.2 & 70 & 20.7 & 339 & 100.0 \\
\hline 1996 & 286 & 68.3 & 13 & 3.1 & 13 & 3.1 & 29 & 6.9 & 78 & 18.6 & 419 & 100.0 \\
\hline 1997 & 306 & 68.5 & 13 & 2.9 & 17 & 3.8 & 29 & 6.5 & 82 & 18.3 & 447 & 100.0 \\
\hline 1998 & 322 & 69.4 & 13 & 2.8 & 26 & 5.6 & 26 & 5.6 & 76 & 16.4 & 463 & 100.0 \\
\hline 1999 & 330 & 66.0 & 32 & 6.4 & 27 & 5.4 & 30 & 6.0 & 80 & 16.0 & 499 & 100.0 \\
\hline 2000 & 312 & 61.5 & 36 & 7.1 & 27 & 5.3 & 32 & 6.3 & 100 & 19.7 & 507 & 100.0 \\
\hline 2001 & 281 & 58.2 & 49 & 10.1 & 30 & 6.2 & 32 & 6.6 & 90 & 18.7 & 482 & 100.0 \\
\hline 2002 & 261 & 54.0 & 50 & 10.4 & 38 & 7.9 & 33 & 6.8 & 101 & 20.9 & 483 & 100.0 \\
\hline 2003 & 235 & 52.5 & 51 & 11.4 & 40 & 8.9 & 41 & 9.2 & 81 & 18.1 & 448 & 100.0 \\
\hline
\end{tabular}

Source: own calculations based on BPS 2004.

The table reveals that more than half of the L\&M scale firms are concentrated in Jepara, whereas about $18 \%$ of the firms are spread out in about 20 districts and over 50 sub-districts outside Jepara. That means that about $18 \%$ of the firms are isolated. Jepara, Klaten, Sukoharjo, and Semarang City are the areas where L\&M wood furniture firms are clustered. Jepara is the largest furniture cluster, whereas Klaten and Sukoharjo are much smaller. Despite the number of L\&M scale firms, around 6,000 small scale firms are found in Jepara, 570 small scale firms in Klaten, and 158 small scale firms in Sukoharjo (BPS, 2004). This does not include micro-scale firms. However, small-scale firms are rarely found in Semarang City. Semarang City is the capital of the Central Java province and a major business center. But most importantly, it is also a port city for the export of wood furniture products.

The description of the firms' sizes in terms of average number of labor $(l a b)$ and average production value per firm (prod) can be seen in Table 3. 
Table 3. The development of firm size according to location

\begin{tabular}{|c|c|c|c|c|c|c|c|c|c|c|c|c|}
\hline \multirow{3}{*}{ Year } & \multirow{2}{*}{\multicolumn{2}{|c|}{ Jepara }} & \multicolumn{10}{|c|}{ Semarang } \\
\hline & & & \multicolumn{2}{|c|}{ Klaten } & \multicolumn{2}{|c|}{ Sukoharjo } & \multicolumn{2}{|c|}{ City } & \multicolumn{2}{|c|}{ Other } & \multicolumn{2}{|c|}{ Total } \\
\hline & $l a b$ & prod & $l a b$ & prod & $l a b$ & prod & $l a b$ & prod & $l a b$ & prod & $l a b$ & prod \\
\hline 1994 & 64 & 450 & 139 & 921 & 155 & 885 & 142 & 626 & 134 & 1,853 & 89 & 811 \\
\hline 1995 & 58 & 486 & 96 & 663 & 101 & 560 & 163 & 1,090 & 104 & 1,264 & 74 & 676 \\
\hline 1996 & 60 & 623 & 107 & 727 & 102 & 575 & 117 & 825 & 95 & 1,496 & 73 & 801 \\
\hline 1997 & 70 & 881 & 111 & 1,648 & 106 & 1,641 & 123 & 1,082 & 110 & 2,320 & 83 & 1,209 \\
\hline 1998 & 87 & 849 & 95 & 2,398 & 89 & 841 & 168 & 2,911 & 167 & 3,415 & 105 & 1,429 \\
\hline 1999 & 77 & 672 & 54 & 618 & 93 & 677 & 171 & 2,959 & 157 & 2,192 & 95 & 1,050 \\
\hline 2000 & 72 & 750 & 63 & 986 & 119 & 1,442 & 154 & 1,872 & 160 & 2,708 & 96 & 1,261 \\
\hline 2001 & 75 & 627 & 48 & 599 & 148 & 945 & 169 & 2,619 & 190 & 2,844 & 104 & 1,190 \\
\hline 2002 & 72 & 532 & 48 & 514 & 115 & 867 & 166 & 2,292 & 114 & 1,828 & 88 & 948 \\
\hline 2003 & 69 & 567 & 50 & 523 & 109 & 889 & 167 & 2,327 & 120 & 1,736 & 88 & 963 \\
\hline
\end{tabular}

Source: own calculations based on BPS 2004.

Note: Labor is measured as number of persons, whereas the production value is measured in millions of rupiah.

As shown in Table 1, using the local classification of firm, the majority of firms, about $75 \%$ to $84 \%$, are medium scale with a labor force of between 20 and 99 workers. The remaining firms employ more than 100 workers, but rarely have more than 500 workers. Approximately 1 to 5 firms over the period of one year have over 500 workers. From the average number of workers and production value, the firms located in Semarang City and "other areas" are relatively large compared to the other districts. This evidence supports previous findings by Visser (1996), who states that small firms tend to be clustered, whereas large ones tend to be isolated or located in business centers. However, this study departs from Visser's argument as it shows that, in isolated areas, firms tend to decrease in size as can be seen from the development of the average number of workers and the production value over time. Moreover, the L\&M firms are found clustered not only in Semarang City, but also in the less small scale density clusters of Klaten and Sukoharjo.

\section{Estimation Results}

This section describes the results of the estimation of the empirical analysis on the effect of cluster/agglomeration factors and international linkage factors on the production value of the large and medium (L\&M) scale wood furniture firms in Central Java, Indonesia; it also presents the estimation of the production function and the interpretation. 


\subsection{Estimation of the production function}

The results of the estimations of the model are presented in Table 4, consisting of seven alternative specifications of our production function model. In specification (1), we estimate the relationship between input factors (labor and energy expenditure) and production value. In specifications (2) and (3), we only describe the effect of time with two different methods, using a linear time trend and year dummies, respectively. In specification (4) we test only the effect of different types of agglomeration economies. In specification (5) we test the effect of the international network. In specification (6), besides the effects of agglomeration economies, we include the effect of having an international linkage. In specification (7) we test the effect of agglomeration, international linkage, and time. The analysis is based on L\&M wood furniture firms for the period 1994 to 2003. 
Table 4. CES production function for production value

\begin{tabular}{|c|c|c|c|c|c|c|c|}
\hline & (1) & (2) & (3) & (4) & $(5)$ & $(6)$ & $(7)$ \\
\hline \multirow[t]{2}{*}{ Constant } & $7.51^{* * *}$ & $7.48^{* * * *}$ & $7.40^{* * * *}$ & $7.41^{* * *}$ & $7.63^{* * *}$ & $7.54^{* * *}$ & $7.43^{* * * *}$ \\
\hline & $(56.20)$ & $(56.10)$ & $(51.60)$ & $(59.60)$ & $(60.00)$ & $(62.20)$ & $(56.90)$ \\
\hline \multirow[t]{2}{*}{ Economies of scale } & $1.05^{* * *}$ & $1.05^{* * *}$ & $1.05^{* * *}$ & $1.05^{* * *}$ & $1.02^{* * * *}$ & $1.01^{* * * *}$ & $1.01^{* * * *}$ \\
\hline & $(77.90)$ & $(77.90)$ & $(77.90)$ & $(75.60)$ & $(72.60)$ & $(70.20)$ & $(70.00)$ \\
\hline \multirow[t]{2}{*}{ Substitution } & -0.01 & -0.02 & -0.03 & -0.06 & -0.04 & -0.08 & -0.11 \\
\hline & $(-0.20)$ & $(-0.20)$ & $(-0.40)$ & $(-0.90)$ & $(-0.60)$ & $(-1.10)$ & $(-1.40)$ \\
\hline \multirow[t]{2}{*}{ Distribution } & $0.75^{* * * *}$ & $0.75^{* * *}$ & $0.76^{* * * *}$ & $0.77^{* * *}$ & $0.77^{* * * *}$ & $0.79^{* * * *}$ & $0.81^{* * * *}$ \\
\hline & $(12.90)$ & $(13.00)$ & $(13.30)$ & $(14.7)$ & $(14.00)$ & $(15.40)$ & $(16.20)$ \\
\hline \multirow[t]{2}{*}{ L\&M density } & & & & $0.24^{* * *}$ & & $0.22^{* * * *}$ & $0.22^{* * * *}$ \\
\hline & & & & $(8.50)$ & & $(7.90)$ & $(7.90)$ \\
\hline \multirow[t]{2}{*}{ Small scale density } & & & & -0.01 & & -0.02 & -0.02 \\
\hline & & & & $(-0.2)$ & & $(-0.70)$ & $(-0.50)$ \\
\hline \multirow[t]{2}{*}{ Urban } & & & & 0.07 & & $0.17^{* * * *}$ & $0.19^{* * * *}$ \\
\hline & & & & $(1.40)$ & & $(7.60)$ & $(8.00)$ \\
\hline \multirow[t]{2}{*}{ Exporter } & & & & & $0.22^{* * *}$ & $0.09^{*}$ & $0.09^{*}$ \\
\hline & & & & & $(3.10)$ & $(1.80)$ & $(1.80)$ \\
\hline \multirow[t]{2}{*}{ Foreign ownership } & & & & & $0.20^{* * *}$ & $0.17^{* * *}$ & $0.17^{* *}$ \\
\hline & & & & & $(8.70)$ & $(2.60)$ & $(2.40)$ \\
\hline \multirow[t]{2}{*}{ Linear time trend } & & $0.01^{* *}$ & & & & & \\
\hline & & $(2.50)$ & & & & & \\
\hline \multirow[t]{2}{*}{1995} & & & 0.08 & & & & 0.09 \\
\hline & & & $(1.30)$ & & & & $(1.40)$ \\
\hline \multirow[t]{2}{*}{1996} & & & $0.16^{* * *}$ & & & & $0.15^{* * *}$ \\
\hline & & & $(2.70)$ & & & & $(2.70)^{\text {**** }}$ \\
\hline \multirow[t]{2}{*}{1997} & & & $0.19^{* * * *}$ & & & & $0.21^{* * *}$ \\
\hline & & & $(3.20)$ & & & & $(3.60)$ \\
\hline \multirow[t]{2}{*}{1998} & & & $0.20 * * *$ & & & & $0.22 * * *$ \\
\hline & & & $(3.40)$ & & & & $(3.80)$ \\
\hline \multirow[t]{2}{*}{1999} & & & $0.14^{* *}$ & & & & $0.14^{* *}$ \\
\hline & & & $(2.50)$ & & & & $(2.50)$ \\
\hline \multirow[t]{2}{*}{2000} & & & $0.18^{* * * *}$ & & & & $0.17^{* * *}$ \\
\hline & & & $(3.10)$ & & & & $(2.90)$ \\
\hline \multirow[t]{2}{*}{2001} & & & $0.24^{* * * *}$ & & & & $0.29^{* * * *}$ \\
\hline & & & $(4.20)$ & & & & $(5.10)$ \\
\hline \multirow[t]{2}{*}{2002} & & & $0.13^{* *}$ & & & & $0.15^{* * *}$ \\
\hline & & & $(2.30)$ & & & & $(2.60)$ \\
\hline \multirow[t]{2}{*}{2003} & & & $0.17^{* * * *}$ & & & & $0.15^{* * * *}$ \\
\hline & & & $(2.90)$ & & & & $(2.60)$ \\
\hline$R^{2}$ & 0.70 & 0.70 & 0.70 & 0.71 & 0.70 & 0.71 & 0.71 \\
\hline$N$ & 4176 & 4176 & 4176 & 4176 & 4176 & 4176 & 4176 \\
\hline \multicolumn{8}{|l|}{ Wald Test $\mu=1$} \\
\hline$F$-Stat & $15.02^{* * *}$ & $14.73^{* * *}$ & $13.47^{* * * *}$ & $12.11^{* * * *}$ & 1.25 & 1.06 & 0.50 \\
\hline \multicolumn{8}{|l|}{ Wald Test $\rho=0$} \\
\hline$F$-Stat & 0.04 & 0.05 & 0.20 & 0.84 & 0.38 & 1.27 & 2.06 \\
\hline
\end{tabular}

Note: absolute $t$-statistics are between parentheses. Statistical significance is indicated with stars, with ${ }^{* * *},{ }^{* *},{ }^{*}$ indicating statistical significance at $1 \%, 5 \%$ and $10 \%$, respectively. 
The results for our key parameters of interest reveal that the constant, $\mu, \rho$ and $\alpha$ change only slightly in the different specifications. All coefficients except $\rho$ are statistically significant at a $1 \%$ level. $\mu$ is close to 1 and $\rho$ is close to zero, showing that the production function is constant returns to scale and that the elasticity of substitution between labor and energy is close to unity. The estimate of $\alpha$ equal to 0.80 demonstrates the dominant role of labor compared to energy. The time variable produces a positive coefficient in the regression (significant at a 5\% level in the CES form), suggesting some generalized improvement in productivity over the 10-year study period. The magnitude of this improvement, due to technological changes or improved methods and procedures is about $1 \%$ per year, but the improvement is prominent in specific years, especially in 1997, 1998, and 2001.

The results on the impact of agglomeration and international linkages reveal interesting findings. Concerning L\&M firm proximity, the results are consistent with the importance of localization externalities in which firms take advantages from the knowledge spillovers from other L\&M firms, thus supporting the prediction of the MAR model. However, in regard to small firm proximity, the results do not support the MAR prediction, meaning that geographical specialization does not affect production value growth. In addition, concerning clustering of diverse firms, specification (7) shows a statistically significant effect, but from specification (5) the effect is not statistically significant. Therefore Jacob's prediction that geographical diversity influences production value growth is not supported by our results. Meanwhile, when we examine the effects of international linkages, specification (7) shows that exporting firms have higher productivity. This is perfectly in line with recent evidence derived from micro-data. The impact of exports is reduced when we control for agglomeration effects pointing at the importance of sorting of productive international firms into high-density regions. Regarding foreign ownership, it is clear from specification (7) that foreign-owned firms have higher productivity, supporting Dunning's argument.

From these results we can predict that firms in an area with a high density of L\&M scale firms have $22 \%$ higher productivity than the other firms; this coefficient is not much different when combined with international network factors. The productivity of firms located in small firm density is not significantly different from other firms. The productivity of firms in an urban area is insignificantly different from other firms, but they are 19\% higher than their counterparts when combined with the impact of an international linkage. Without considering the international network and time factors, the productivity difference is not significant. However, the productivity increases when combined with the international network and time factors. Meanwhile, compared to cluster factors the role of an international linkage is stronger. For instance, after considering location factor, exporting firms are 9\% higher in productivity than other firms; it declines from $22 \%$ when the impact of location (urban area or small scale firm density) are not accounted for. Foreign-owned firms are 17\% higher in productivity than their counterpart, a slight decline from $20 \%$ when not considering location factors. 


\subsection{Interpretation}

The model proposed and tested in this study explains a substantial portion of the productivity differences between groups of firms over the 10-year period covered by the data. The fully specified model accounts for about $70 \%$ of production value variation. Probably most of the remaining variables are due to special factors, in particular factory factors, such as management or other factory-specific situations. From the result above, several important aspects need to be underlined.

First, the dominant share of labor over energy described by the production function indicates that the wood furniture industry in Central Java is rather labor intensive. The positive elasticity of substitution between labor and energy denotes that the use of energy representing the use of machinery in the production process could, to a certain extent, be replaced by labor. Meanwhile, the constant returns to scale that characterize the production function implies that additional inputs produce proportionally more outputs. Producing traditional products, the wood furniture industry is characterized by low barriers to entry or exit from the industry, which also points to the high competition in the industry. In the L\&M firms, the low barriers to entry can also be analyzed from the production value. A large gap exists between the largest and the smallest firms in this industry; numerous firms only produce in real value, about 20 million rupiah a year, whereas the largest firms produce more than 4,000 times that of the smallest firms. In terms of labor, the largest firms employ more than 100 times the number of laborers employed by the smallest firms in this group. Noteworthy is that the production process (by most of the L\&M firms) is supported by about 9,000 small scale firms scattered across the province but concentrated in Jepara that employ 5 to 19 workers. This number does not include the micro-firms, which have fewer than five workers. In other words, the technology applied by the firms in the wood furniture industry is heterogeneous; several large and medium firms apply relatively modern technology, but many medium firms use medium technology and are also supported by small scale firms that use very simple and traditional technology.

Second, as hypothesized in Section 2, the co-location of firms indeed tends to stimulate the creation and diffusion of knowledge. From the statistical tests, we can conclude that firms located in a cluster with high L\&M firm specialization are more productive. What is striking is that the proximity of small scale firms has no effect on the production value. The evidence presented above suggests that specialization of L\&M firms - not specialization of small scale firms - contributes to productivity. There are at least two reasons that may explain this result. First, there is a technological gap between small scale firms and L\&M scale firms, as discussed above, so that quality products made by small firms cannot fulfill the requirements of L\&M firms. Second, L\&M firms prefer to do business with medium sized suppliers rather than small scale suppliers, because it is more efficient; it means that L\&M scale firms benefit from technological spillovers of other L\&M scale firms but not from small scale firms. According to Shaver 
and Flyer (2000), firms with relatively more advanced technology, usually L\&M scale firms, will obtain minimal benefits from access to technology from neighboring firms that have poor technology. Furthermore, firms located in urban areas do not differ markedly from firms outside the urban areas.

Third, in Section 2 we hypothesized a linkage with foreign partners by being inserted in a global buyer value chain or being involved in an equity partnership, which increases firm performance. These two hypotheses - tested using the Central Java L\&M wood furniture firm data - support the arguments. Being linked with foreign buyers or a foreign partner might function as an effective channel of knowledge diffusion and interactive learning, because they can provide a common knowledge base via product requirements or a transfer of specific technology. As a traditional industry, firms in the wood furniture industry can survive with a certain level of technology and rely largely on labor. However, increasing competition in the world market requires continuous upgrading, not only from the production process and product, but beyond. Wood furniture products are fashionable and customer demands change drastically over time. For firms, product development, especially in relation to the design and choice of technology, is important in giving a competitive advantage in the international market as well as within the domestic market in competing with imported products. Wood furniture firms therefore need to take advantage of the possibility of being inserted into global value chains or partnerships with foreigners.

Meanwhile, the wood furniture industry during the period of observation is growing. From 1994 to 2003 , the production value of firms has increased significantly, ranging from $14 \%$ to $29 \%$, compared to the production value in 1994. A profound increase occurred in 1997 and 1998, and particularly in 2001. During the 10 years of observation, the wood furniture industry in Central Java has grown on average $1 \%$ per year. However, when compared to the growth in world demand, the growth of the wood furniture industry in this region is relatively low. Similar to many Asian countries, the industry benefited from the Indonesian currency devaluation. In mid-1997 continuing to 1998, Indonesia was hit hard by the monetary crisis, in which the rupiah was devaluated against the US dollar by more than $300 \%$; the ensuing reduction in the price of furniture products in the international market led to a soar in demand. In 2001, the Indonesian rupiah was devaluated once again, causing an increase in demand. The change in production value and the exchange rate is shown below in Figure 2. From this figure, we can observe that the wood furniture production value of L\&M firms in Central Java is sensitive to changes in the exchange rate in the early phase of industry growth but it is less sensitive after 2001. Some internal and external factors that have been mentioned above explain the changes. 
Figure 2. The pattern of development of US \$ in rupiah and production value

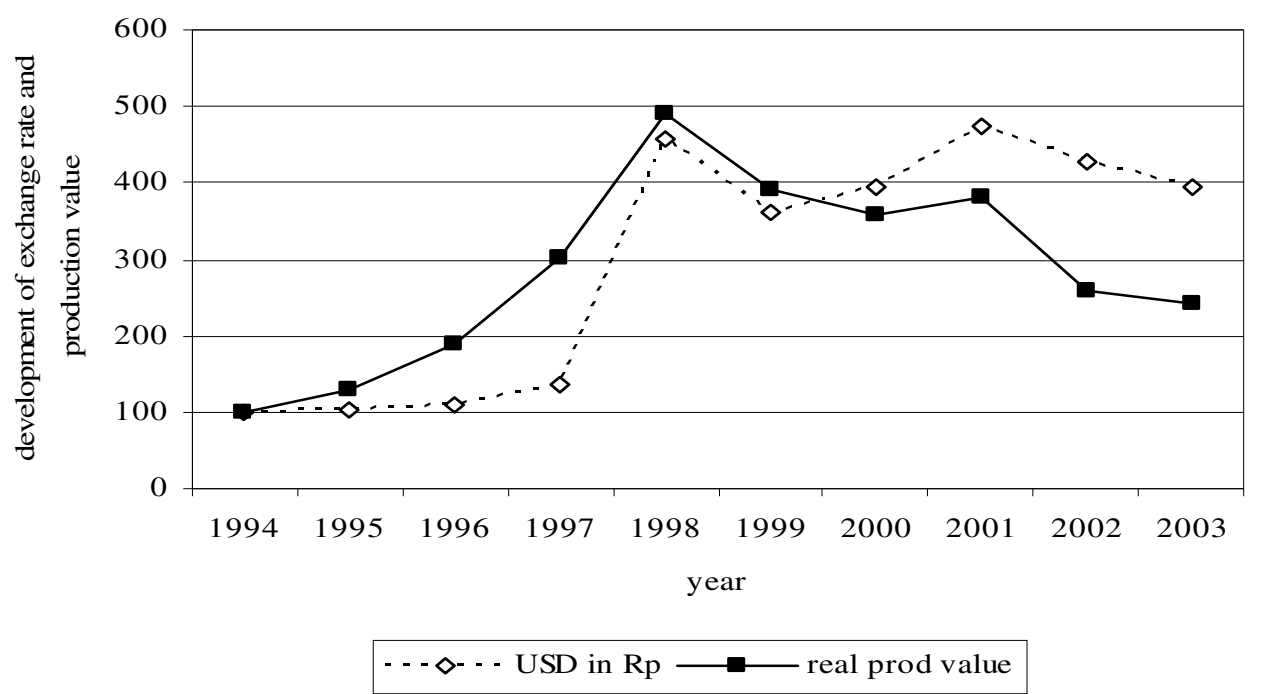

To summarize, firms that are located close to L\&M firms have higher productivity, in contrast to firms that locate near to small scale firms. Moreover, firms with well-established networks with foreign buyers or equity partnerships are more productive.

\section{Conclusion}

The aim of this paper was to test whether different types of agglomeration economies and involvement in the international network stimulate the performance of L\&M wood furniture firms. Our empirical analysis shows that clustering of L\&M specialized firms and linking to the international network by exporting, or by establishing foreign-owned partnerships increases the production value. The outcome suggests that firms are more productive when located in a region with a relatively high number of L\&M wood furniture firms. Moreover, firms are more productive when linked to the international network in order to become exporters or when they build partnerships with foreign-owned firms. However, clustering small scale specialized firms, clustering diverse firms does not make any difference in productivity.

The clustering of L\&M specialized firms and international network linkages - in terms of exporter and foreign ownership - foster knowledge spillovers and thus firm performance. Knowledge spillovers from L\&M sized firms are essential to the improvement of efficiency, which supports the MAR argument. Knowledge spillovers from an international linkage support the thesis of Gereffi and Dunning.

Note that we have used a relatively crude measure of agglomeration economies and international linkages. A more in-depth examination might shed further light on how agglomeration and international linkage affect firm performance. In addition, more research needs to focus on the unraveling of the impact 
of agglomeration economies and international linkage factors on firm performance. Our analysis shows these factors to have a highly-interrelated effect on the performance of firms. We believe that the geographical implications of these international linkage factors should be further explored empirically in order to gain a better understanding of their impact. Such an approach would most certainly benefit by taking a more dynamic perspective, in which the spatial evolution of an industry is analyzed in terms of the innovation and diffusion of competence. This research only begins to explore this issue existing in the research of industrial clusters.

\section{References}

Acs, Z (2002) Innovation and the Growth of Cities, Cheltenham: Edward Elgar.

Alperovich G (1980) Regional Elasticities of Substitution. Journal of Regional Science 20: 503-512.

Arnold JM, Javorcik BS (2005) Gifted Kids or Pushy Parents? Foreign Acquisitions and Plant Performance in Indonesia, World Bank Policy Research Paper, no. 3193, Washington DC.

Arrow KJ (1962) The Economic Implications of Learning by Doing. Review of Economic Studies 29: 155173.

Arrow KJ, Chenery BM, Inkas BS, Solow RM (1961) Capital-Labor Substitution and Economic Efficiency. Review of Economics and Statistics 43: 225-254.

Asheghian P (1982) Comparative Efficiencies of Foreign Firms and Local Firms in Iran. Journal of International Business Studies 12: 113-120.

Aw BY, Chung S, Roberts M (2000) Productivity and Turnover in the Export Market: Micro Evidence from Taiwan and South Korea. World Bank Economic Review 14: 65-90.

Aw BY, Hwang AR (1995) Productivity in the Export Market: A Firm Level Analysis. Journal of Development Economics 47 (2): 313-332.

Aw BY, Xiaomin C, Mark R (1997) Firm Level Evidence on Productivity Differentials, Turnover, and Exports in Taiwanese Manufacturing. NBER Working paper, no. 6235, Cambridge, MA.

Barnett AH, Reutter K, Thompson H (1998) Electricity Substitution: Some Local Industrial Evidence. Energy Economics 20: 411-419.

Bellak C (2004) How Domestic and Foreign Firms Differ and Why Does It Matter? Journal of Economic Surveys 18: 483-514.

Bernard A, Jensen JB (1995) Exporters, Jobs and Wages in US Manufacturing: 1976-1987. Brookings Papers on Economic Activity: Microeconomics 1995: 67-112.

Bernard A, Jensen JB (1999) Exceptional Exporters Performance: Cause, Effect or Both? Journal of International Economics 47: 1-25. 
Berndt ER, Jorgenson D (1973) Production Structure. In Jorgenson DW, Houthakker HS (eds) US Energy Resources and Economic Growth. Final report to the Ford Foundation Energy Policy Project. Washington, DC.

Berndt ER, Wood DO (1975) Technology, Prices, and the Derived Demand for Energy. Review of Economics and Statistics 57: 259-268.

BPS (2004) Badan Pusat Statistik: Annual Manufacturing Survey 1994-2003. Jakarta.

Burney N, Al-Matrouk F (1996) Energy Conservation in Electricity Generation: A Case Study of the Electricity and Water Industry in Kuwait. Energy Economics 18: 69-79.

Calem PS, Carlino GA (1991) Urban Agglomeration Economies in the Presence of Technical Change. Journal of Urban Economics 29(1): 82-95.

Cameron T, Schwartz SL (1980) Inflationary Expectations and the Demand for Capital, Labor, and Energy in Canadian Manufacturing Industries. In Garret HB, Mullen EG, Ziemba WT (eds), Energy Policy Modeling: U.S. and Canadian Experiences Matinus Nijhoff Publishing, Boston.

Clerides S, Lach S, Tybout J (1998) Is Learning by Exporting Important? Micro-Dynamic Evidence from Columbia, Mexico and Morocco. Quarterly Journal of Economics 113: 903-947.

Criscuolo and Martin (2003) Multinationals, and US Productivity Leadership: Evidence from Britain, CERIBA Discussion Paper, United Kingdom.

Delgado M, Farias J, Ruano S (2002) Firm Productivity and Export Markets: A Non-Parametric Approach. Journal of International Economics 57(2): 397-422.

Denny M, Fuss M, Waverman L (1981) Substitution Possibilities for Energy: Evidence from US and Canadian Manufacturing Industries. In. Berndt ER, Field BC (eds), Modeling and Measuring Natural Resource Substitution. MIT Press, Cambridge.

Doms ME, Jensen JB (1998) Comparing Wages, Skills, and Productivity Between Domestic and Foreign Owned Manufacturing Establishments in the United States. In Baldwin R, Lipsey R, Richardson J (eds) Geography and Ownership as Bases for Economic Accounting. University of Chicago Press.

Douma S, George R, Kabir R (2006) Foreign and Domestic Ownership, Business Groups and Firm Performance: Evidence from a Large Emerging Market. Strategic Management Journal 27: 637-657.

Dunning JH (1993) Multinational Enterprises and the Global Economy. Wokingham: Addison-Wesley.

Duranton G, Puga D (2004) Micro-foundations of urban agglomeration economies. In: Henderson JV \& Thisse JF (eds), Handbook of Regional and Urban Economics, Elsevier.

Ernst D, Kim L (2002) Global Production Networks, Knowledge Diffusion, and Local Capability Formation. Research Policy 31: 1417-1429

Field BC, Grebenstein C (1980) Capital-Energy Substitution in U.S. Manufacturing. Review of Economics and Statistics 62: 207-212. 
Gereffi G (1999) International Trade and Industrial Upgrading in the Apparel Commodity Chains. Journal of International Economics 48(1): 37-70.

Glaeser EL, Kallal HD, Scheinkman JA, Shleifer A (1992) Growth in Cities. Journal of Political Economics 100: 1126-1152.

Glaeser EL, Maré DC (2001), Cities and Skills. Journal of Labor Economics 19: 316-342.

Grant RM (1987) Multinationality and Performance among British Manufacturing Companies. Journal of International Business Studies 17: 79-89.

Griffin JM, Gregory PR (1976) An Intercountry Translog Model of Energy Substitution Responses. American Economic Review 66: 845-857.

Griffith R, Simpson H (2003) Characteristics of Foreign-Owned Firms in British Manufacturing. NBER Working Paper, no. 9573, Cambridge, MA.

Groot, HLF De, Poot J, \& Smit MJ (2009) Agglomeration, Innovation and Regional Development: Theoretical Perspectives and Meta-Analysis. In: Capello R \& Nijkamp P (eds), Handbook of regional growth and development theories. Cheltenham: Edward Elgar.

Halvorsen R, Ford J (1979) Substitution Among Energy, Capital, and Labor Inputs in U.S. Manufacturing. In: Pindyck RS (ed) Advances in the Economics of Energy and Resources: The Structure of the Energy Markets. The JAI Press 1.

Howensteine NG, Zeile WJ (1994) Characteristics of Foreign-Owned U.S. Manufacturing Establishments. Survey of Current Business, January: 34-59.

Jacobs J (1969) The Economy of Cities. London: Jonathan Cape.

Kemfert C (1998) Estimated Substitution Elasticities of a Nested CES Production Function Approach for Germany. Energy Economics 20: 249-264.

Klump R, Preissler H (2000) CES Production Functions and Economic Growth. Scandinavian Journal of Economics 102(1): 41-56.

Koetse MJ, de Groot HLF, Florax RJGM (2008) Capital-Energy Substitution and Shifts in Factor Demand: A Meta-Analysis. Energy Economics 30(5): 2236-2251.

Kumar N (1984) Social Cost-benefit Analysis of an Export-Oriented Project with Foreign Collaboration in India. Industry \& Development 10: 9-46.

Marshall A (1920) Principles of Economics, $8^{\text {th }}$ ed. London: Macmillan.

Melo PC, Graham DJ, Noland RB (2008) A meta-analysis of estimates of urban agglomeration economies. Regional Science and Urban Economics 39: 332-342.

Moomaw RL (1983) Is Population Scale a Worthless Surrogate for Business Agglomeration Economies? Regional Science and Urban Economics 13: 525-545. 
Nakamura R (1985) Agglomeration Economies in Urban Manufacturing Industries: A Case of Japanese Cities. Journal of Urban Economics 17: 108-124.

Pindyck RS (1979) Inter-fuel Substitution and Industrial Demand for Energy: An International Comparison. Review of Economics and Statistics 61(2): 169-179.

Porter M (1990) The Competitive Advantage of Nations. London: Macmillan.

Romer P (1986) Increasing Returns and Long run Growth. Journal of Political Economy 94: 1002-1037.

Rondinelli DA (1983) Secondary Cities in Developing Countries: Policies for Diffusing Urbanisation. Sage Publications, Beverly Hills.

Rosenthal S, Strange W (2003) Geography, Industrial Organization, and Agglomeration. Review of Economics and Statistics 85(2): 377-393.

Schmitz H (1999) Global Competition and Local Cooperation: Success and Failure in the Sinos Valley, Brazil. World Development 27(9):1627-1650

Shaver JM, Flyer F (2000) Agglomeration Economies, Firm Heterogeneity, and Foreign Direct Investment in the United States. Strategic Management Journal 21: 1175-1193.

Venables AJ (2005) Spatial Disparities in Developing Countries: Cities, Regions, and International Trade. Journal of Economic Geography 5(1): 3-21

Visser J (1996) Local Sources of Competitiveness, Spatial Clustering and Organization Dynamics in Small Scale Clothing in Lima, Peru. VU University Amsterdam, PhD thesis.

Walton A (1981) Variations in the Substitutability of Energy and Nonenergy Inputs: The Case of the Middle Atlantic Region. Journal of Regional Science 21: 411-420.

Webster D, Muller L (2000) Urban Competitiveness Assessment in Developing Country Urban Regions: The Road Forward. World Bank, Washington, D.C. 


\section{Appendix. Results for Cobb-Douglas production function}

To provide more insight into the impact of externalities on firm performance and analyze the robustness of the results, this section carries out an alternative analysis using the Cobb-Douglas production function. The output of the Cobb-Douglas production function shows similar estimation results. The coefficients of estimation from seven alternative equations are presented in Table A.1. Specification (1) presents the results when external factors are not considered, specifications (2)-(5) when the estimations partially consider externality factors and the time factor, specification (6) when all externalities are considered regardless of time, and specification (7) when external factors and time are estimated jointly.

The table illustrates that the hypotheses that the sum of $\alpha$ and $\beta$ is equal to one cannot be rejected in the last three joint equations. In general, the Cobb-Douglas specifications provide a good fit to the production value data of the wood furniture industry in Central Java. The table above examines the robustness of the findings by reporting the results in different equations. Note the similarity of the coefficients for all the variables except $\ln (L)$ and $\ln (K)$, regardless of the estimated functional form. Hypotheses tests show that the CES form is not significantly different from the Cobb-Douglas (at the 5\% level). 
Table A.1. Results with Cobb-Douglas production function

\begin{tabular}{|c|c|c|c|c|c|c|c|}
\hline \multicolumn{8}{|c|}{ Specification } \\
\hline & (1) & (2) & (3) & (4) & $(5)$ & (6) & $(7)$ \\
\hline \multirow[t]{2}{*}{ Constant } & $7.48^{* * *}$ & $7.46^{* * *}$ & $7.35^{* * *}$ & $7.32^{* * *}$ & $7.56^{* * * *}$ & $7.43^{* * *}$ & $7.29^{* * * *}$ \\
\hline & $(128.50)$ & $(126.40)$ & $(96.90)$ & $(106.70)$ & $(127.60)$ & $(105.20)$ & $(85.30)$ \\
\hline \multirow[t]{2}{*}{ Labor } & $0.77^{* * *}$ & $0.78^{* * * *}$ & $0.78^{* * * *}$ & $0.76^{* * * *}$ & $0.75^{* * *}$ & $0.74^{* * *}$ & $0.74^{* * * *}$ \\
\hline & $(37.60)$ & $(37.50)$ & $(36.90)$ & $(37.30)$ & $(36.40)$ & $(36.00)$ & $(35.70)$ \\
\hline \multirow[t]{2}{*}{ Energy } & $0.28^{* * *}$ & $0.27^{* * * *}$ & $0.28^{* * *}$ & $0.29^{* * *}$ & $0.27^{* * * *}$ & $0.27^{* * * *}$ & $0.27^{* * * *}$ \\
\hline & $(23.60)$ & $(22.60)$ & $(22.20)$ & $(23.00)$ & $(2.50)$ & $(21.40)$ & $(20.60)$ \\
\hline \multirow[t]{2}{*}{ L\&M density } & & & & $0.24^{* * *}$ & & $0.22^{* * * *}$ & $0.22^{* * *}$ \\
\hline & & & & $(8.50)$ & & $(7.80)$ & $(7.90)$ \\
\hline \multirow[t]{2}{*}{ Small scale density } & & & & -0.01 & & -0.02 & -0.02 \\
\hline & & & & $(-0.30)$ & & $(-0.80)$ & $(-0.70)$ \\
\hline \multirow[t]{2}{*}{ Urban area } & & & & $0.08^{*}$ & & $0.17^{* * * *}$ & $0.18^{* * * *}$ \\
\hline & & & & $(1.60)$ & & $(7.50)$ & $(8.00)$ \\
\hline \multirow[t]{2}{*}{ Exporter } & & & & & $0.22^{* * *}$ & $0.10^{* * * *}$ & $0.10^{* * *}$ \\
\hline & & & & & $(3.10)$ & $(2.00)$ & $(2.00)$ \\
\hline \multirow[t]{2}{*}{ Foreign ownership } & & & & & $0.19^{* * *}$ & $0.17^{* * *}$ & $0.17^{\text {**** }}$ \\
\hline & & & & & $(8.70)$ & $(2.60)$ & $(2.50)$ \\
\hline \multirow[t]{2}{*}{ Trend } & & $0.01^{* * *}$ & & & & & \\
\hline & & $(2.50)$ & & & & & \\
\hline \multirow[t]{2}{*}{1995} & & & 0.08 & & & & 0.09 \\
\hline & & & $(1.30)$ & & & & $(1.40)$ \\
\hline \multirow[t]{2}{*}{1996} & & & $0.16^{* * *}$ & & & & $0.15^{* * *}$ \\
\hline & & & $(2.70)$ & & & & $(2.60)$ \\
\hline \multirow[t]{2}{*}{1997} & & & $0.19^{* * *}$ & & & & $0.20^{\text {**** }}$ \\
\hline & & & $(3.10)$ & & & & $(3.50)$ \\
\hline \multirow[t]{2}{*}{1998} & & & $0.20^{* * * *}$ & & & & $0.22^{* * *}$ \\
\hline & & & $(3.30)$ & & & & $(3.60)$ \\
\hline \multirow[t]{2}{*}{1999} & & & $1.40^{* *}$ & & & & $0.14^{* *}$ \\
\hline & & & $(2.40)$ & & & & $(2.40)$ \\
\hline \multirow[t]{2}{*}{2000} & & & $0.18^{* * * *}$ & & & & $0.16^{* * * *}$ \\
\hline & & & $(3.00)$ & & & & $(2.70)$ \\
\hline \multirow[t]{2}{*}{2001} & & & $0.24^{* * * *}$ & & & & $0.28^{* * *}$ \\
\hline & & & $(4.20)$ & & & & $(4.90)$ \\
\hline \multirow[t]{2}{*}{2002} & & & $0.13^{* *}$ & & & & $0.14^{* *}$ \\
\hline & & & $(2.30)$ & & & & $(2.50)$ \\
\hline \multirow[t]{2}{*}{2003} & & & $0.17^{* * *}$ & & & & $0.15^{* * *}$ \\
\hline & & & $(2.80)$ & & & & $(2.60)$ \\
\hline$R^{2}$ & 0.70 & 0.70 & 0.70 & 0.71 & 0.70 & 0.71 & 0.71 \\
\hline$F$-Stat & 4986.54 & 3330.03 & 912.41 & 2073.71 & 2567.91 & 1513.75 & 668.45 \\
\hline$N$ & 4307 & 4307 & 4307 & 4307 & 4307 & 4307 & 4307 \\
\hline \multicolumn{8}{|l|}{ Wald Test $\alpha+\beta=1$} \\
\hline$F$-Stat & 15.15 & 14.92 & 13.98 & 12.66 & 1.50 & 1.32 & 0.78 \\
\hline Prob & 0.00 & 0.00 & 0.00 & 0.00 & 0.22 & 0.25 & 0.38 \\
\hline
\end{tabular}

Note: absolute $t$-statistics are between parentheses. Statistical significance is indicated with stars, with ${ }^{* * *},{ }^{* *},{ }^{*}$ indicating statistical significance at $1 \%, 5 \%$ and $10 \%$, respectively. 